\title{
EFEKTIVITAS BUKU “PELANGI HATIKU” DALAM MENURUNKAN AGRESI SISWA SEKOLAH DASAR
}

\section{THE EFFECTIVENESS "PELANGI HATIKU” BOOK TO REDUCE AGGRESSION ON ELEMENTARY SCHOOL STUDENTS}

\author{
Nur Haris 'Ali \\ Dian Sari Utami \\ Fakultas Psikologi dan IImu Sosial Budaya Universitas Islam Indonesia Yogyakarta \\ E-mail: harisnurali@gmail.com
}

\begin{abstract}
This research aims to find the effectiveness of aggression decent on elementary school's students using Book "Pelangi Hatiku". Subjects of this research were 19 students in experiment group. Aggression were measured by aggression questioner that constructed by researcher based on aggression theory of Buss and Perry (1992) and Book "Pelangi Hatiku" was constructed by Utami (2004) with some permissions to revision by researcher. The result of analysis data found that student's aggression was descend after got Book "Pelangi Hatiku" as a treatment. Book "Pelangi Hatiku" is able to be a media alternative for the students qualitatively to disclosure the idea, emotions, and hidden experiences.
\end{abstract}

Key words: Aggression, Elementary School's Student, Book "Pelangi Hatiku".

\begin{abstract}
Abstrak
Penelitian ini bertujuan untuk mengetahui efektivitas penurunan agresivitas pada siswa sekolah dasar yang menggunakan Buku "Pelangi Hatiku" (BPH). Subjek dalam penelitian ini berjumlah 19 siswa dalam kelompok eksperimen. Agresivitas diukur menggunakan skala agresivitas berdasarkan teori dari Buss dan Perry (1992) dengan perlakuan berupa Buku "Pelangi Hatiku" yang disusun oleh Utami (2004) dengan beberapa revisi dari peneliti. Hasil analisis data menunjukkan bukti bahwa tingkat agresivitas siswa mengalami penurunan setelah diberikan perlakuan BPH. Secara kualitatif, BPH mampu menjadi alternatif media bagi para siswa untuk mengungkapkan ide, emosi, dan pengalaman yang dirasakan.
\end{abstract}

Kata kunci: Agresivitas, Siswa Sekolah Dasar, Buku "Pelangi Hatiku". 
Perilaku agresif siswa Sekolah Dasar (SD) bukan merupakan hal baru bagi guru dan orang tua. Perilaku agresif tersebut sudah menjadi masalah sosial yang dipercaya bisa berpengaruh bagi pertumbuhan dan perkembangan masa depan anak, lebih-lebih ketika anak berkembang ke usia remaja maupun dewasa. Perilaku agresif yang terjadi di lingkungan sekolah, selain dapat mengganggu proses pembelajaran, juga dapat menyebabkan siswa cenderung melakukan pembiasaan pada perilaku merugikan tersebut (Anantasari, 2006; Winarsih, 2007).

Dampak utama dari perilaku agresif adalah anak mengalami kesulitan dalam berinteraksi dengan peer (teman sebaya). Bahkan, dalam penelitian Kokko, Pulkkinen, Huesmann, Dubow, dan Boxer (2009) disebutkan akan muncul bentuk perilaku agresif yang sangat berbeda ketika anak sudah memasuki dunia remaja dan dewasa. Farrington (Sari \& Kurniawan, 2004) dalam penelitiannya juga menemukan bahwa agresivitas di masa anak-anak merupakan faktor risiko bagi perkembangan di masa berikutnya. Hasil penelitian Farrington memperlihatkan bahwa 40 persen dari anak-anak yang sangat agresif pada umur sembilan tahun, termasuk ke dalam kelompok paling agresif saat mereka berumur 17 tahun dan 14 persen dari anak-anak yang sangat agresif pada umur sembilan tahun, melakukan kejahatan dengan kekerasan pada umur 21 tahun. Sebagai perbandingan, hanya 27 persen dari anak-anak yang sebelumnya nonagresif masuk ke dalam kelompok sangat agresif pada saat mereka berumur 17 tahun dan hanya empat persen dari mereka yang melakukan kejahatan dengan kekerasan. Penelitian Farrington tersebut juga dikuatkan oleh penelitian Tremblay (2008) yang menyebutkan bahwa seorang anak di masa usia sekolah dasar akan menghadapi masalah agresi fisik secara signifikan di masa mendatang.

Dewasa ini, berita tentang terlibatnya para siswa dalam berbagai bentuk perilaku agresif seperti pemukulan, perkelahian atau tindak kekerasan lainnya semakin sering muncul di sejumlah media. Data Pusat Komisi Nasional Perlindungan Anak (Komnas PA) merilis jumlah kekerasan yang terjadi antar siswa tahun 2011 sebanyak 339 kasus. Sementara pada tahun sebelumnya, data dari Komisi Perlindungan Anak Indonesia (KPAI) menyebutkan bahwa pengaduan kekerasan yang dilakukan oleh anak sebanyak 107 kasus, dengan bentuk kekerasan, seperti kekerasan fisik, psikis, penganiayaan hingga pembunuhan (Kompas, 23/12/2011). Sejumlah kasus yang terjadi di atas merupakan manifestasi dari sifat agresif yang ada dalam diri anak (Sari \& Kurniawan, 2004). Padahal, menurut Syaodih (2003), anak yang memasuki usia SD seharusnya sudah mulai sadar bahwa pengungkapan 
emosi secara kasar tidak dapat diterima dalam masyarakat. Anak seharusnya juga mulai belajar untuk mengendalikan dan mengontrol ekspresi emosi yang dirasakan.

Dalam kajian psikologi, perilaku agresif mengacu pada beberapa jenis perilaku baik secara fisik maupun mental, yang dilakukan dengan tujuan menyakiti seseorang (Berkowitz, 2003). Jenis perilaku yang tergolong agresif antara lain adalah fighting (berkelahi), namecalling (mengata-ngatai), bullying, hazing (mempelonco), making threats (mengancam) dan berbagai perilaku intimidasi lainnya (Wilson \& Lipsey, 2007). Dengan demikian, sebuah perbuatan dapat digolongkan sebagai perilaku agresif jika perbuatan tersebut sengaja dilakukan untuk menyakiti atau merugikan orang lain. Seorang siswa yang karena perbuatannya tidak dengan sengaja menyakiti temannya, maka tidak digolongkan berperilaku agresif, berbeda dengan siswa yang sengaja menyerang temannya dengan tujuan menyakiti.

Berbagai pendekatan untuk mengatasi perilaku agresif, seperti pemberian nasehat, hukuman fisik, atau pengalihan perhatian tampaknya belum membuat perilaku agresif siswa menurun. Bahkan, beberapa pendekatan tersebut justru membuat agresivitas siswa meningkat. Pemberian hukuman fisik, misalnya, bukanlah solusi yang tepat untuk menangani perilaku agresif siswa. Siswa yang sering mendapatkan hukuman fisik, menurut beberapa penelitian, cenderung lebih agresif dan menggunakan kekerasan untuk menyelesaikan masalah setelah diberikannya hukuman tersebut. Hasil penelitian longitudinal selama 20 tahun yang dirilis Canadian Medical Association Journal, Februari 2012, memaparkan fakta bahwa anak-anak yang sering ditampar, dipukul, atau diteriaki ketika mereka bertindak nakal cenderung meniru perilaku yang didapatkannya saat dewasa nanti (Tempo, 8/2/2012). Ditambahkan, anakanak yang sering mendapatkan pukulan atau cubitan dari orangtua akan tumbuh dengan tingkat agresi yang tinggi terhadap orangtua, saudara, teman sebaya, atau pasangannya di kemudian hari. Hal tersebut terjadi karena anak justru belajar bahwa setiap kali mereka marah atau kesal bisa diekspresikan dengan cara memukul (Kompas, 7/2/2012).

Faktor penyebab munculnya perilaku agresif sangat beragam, tidak tunggal, tetapi secara garis besar dapat dikelompokkan menjadi dua penyebab, yaitu biologis dan lingkungan (Mundia, 2006). Kedua faktor tersebut menyebabkan terhambatnya perkembangan aspek emosi dan sosial pada siswa yang bersangkutan. Faktor biologis, menurut Mundia (2006), terdiri atas gen, kromosom, hormon, sistem otak, dan kimia darah. Sementara faktor lingkungan meliputi lingkungan sosial- 
belajar, faktor sekolah, dan pola asuh orang tua yang permisif. Selain itu faktor teman sebaya juga merupakan sumber yang paling memengaruhi anak. Faktor teman sebaya merupakan faktor yang sering terjadi ketika perilaku agresif dilakukan secara berkelompok. Ada teman yang memengaruhi anak agar melakukan tindakan-tindakan agresif terhadap anak lain. Faktor-faktor di atas sangat kompleks dan saling memengaruhi satu sama lain (Mundia, 2006).

Sementara itu, hasil studi pendahuluan Akbar dan Afiatin (2009) yang dilakukan di salah satu sekolah, menunjukkan bahwa sebagian besar siswa memiliki kebutuhan untuk dapat mengelola emosi terutama emosi-emosi negatif yang dirasakan, mengekpresikan emosi secara tepat, dan membutuhkan adanya media yang mampu menekankan pada proses-proses pengelolaan emosi. Hasil studi Akbar dan Afiatin menguatkan penelitian Utami dan Kumara (2007) yang menemukan bahwa sebuah media sangat dibutuhkan anak untuk mengelola emosi-emosi yang dirasakan. Selain untuk mengontrol dan mengungkapkan emosi, media tersebut juga harus mampu membantu anak agar tercapai kondisi tubuh yang seimbang serta dapat menampung katarsis fisik dan mental karena ekspresi-ekspresi emosi anak yang ditekan.

Untuk itu, usaha yang dilakukan dalam penelitan ini dalam rangka memperkenalkan emosi, pengelolaan emosi dan pengelolaan pada gangguan suasana hati adalah dengan cara memberikan sebuah media kepada anak. Serangkaian perasan, pikiran, pengalaman dan emosi pada anak akan dituangkan dalam sebuah media tersebut yang diberi nama Buku "Pelangi Hatiku" (Utami \& Kumara, 2007).

Buku "Pelangi Hatiku" (BPH) merupakan media seni yang meminta anak untuk menuliskan dan menggambarkan perasaan, pikiran, pengalaman, dan emosi yang dirasakan. Media BPH tersebut diharapkan mampu mengubah perasaan anak dan menekankan pada proses-proses pengelolaan emosi maupun gangguan suasana hati. Dengan demikian, melalui media tersebut, diharapkan dapat terlihat penurunan agresivitas anak yang menggunakan $\mathrm{BPH}$ serta berapa sumbangan efektivitas penurunan agresi tersebut yang terjadi pada anak-siswa sekolah dasar yang menggunakan $\mathrm{BPH}$.

Sejumlah literatur menyebutkan bahwa aktivitas menuliskan pengalaman emosional memiliki manfaat dalam beberapa hal, di antaranya mengenalkan, mengekspresikan, melepaskan dan mengurangi emosi-emosi negatif yang dirasakan (Pennebaker, 1997a). Menulis, menurut Pennebaker (1997b), juga mampu menjadikan suasana hati semakin membaik, pandangan yang lebih positif dan kesehatan fisik yang lebih baik. Selain itu, perubahan belajar 
individu menjadi meningkat setelah dilakukan serangkaian penelitian terkait menulis pengalaman emosional terhadap subjek bersangkutan.

Sementara Anoviyanti (2008) menjelaskan bahwa menggambar, yang merupakan bagian dari seni, memiliki manfaat untuk mencatat dan menyampaikan berbagai tingkatan emosi, dari rasa nyaman hingga kesedihan yang terdalam, dari kejayaan hingga trauma. Jika dilihat dalam ruang lingkup yang lebih luas, lanjut Anoviyanti (2008), maka dengan menggambar individu mampu menjelaskan pengalaman inner experiences (pengalaman batin) tanpa harus menggunakan kata-kata. Ditambahkan, sebuah seni gambar juga memiliki manfaat agar apa yang tidak mampu dikatakan dengan bahasa verbal pada umumnya, dapat dikomunikasikan dengan bahasa rupa. Dengan demikian, apa yang selama ini tidak dapat dikatakan menjadi terkatakan.

Adapun perbedaan penelitian ini dengan penelitian-penelitian terdahulu adalah masih banyak para peneliti terdahulu yang mengambil subjek pada rentang usia remaja atau dewasa. Beberapa penelitian yang bisa disebutkan antara lain penelitian Siswanto dan Prawitasari (2003) yang meneliti pengaruh menulis pengalaman emosional terhadap simtom-simtom depresi pada subjek mahasiswa, penelitian Wardhani (2007) yang meneliti penerapan terapi menulis untuk menurunkan agresi pada subjek remaja dengan lambat belajar, dan penelitian Lestari (2010) yang meneliti hubungan antara kebiasaan menulis buku harian dengan keterampilan intrapersonal pada subjek remaja akhir.

Satu-satunya penelitian dengan tema serupa yang mengambil subjek anak-anak, yang peneliti temukan, adalah penelitian Utami dan Kumara (2007). Penelitian tersebut mengambil subjek pasien anak rawat inap (hospitalized children) dengan fokus penelitian manajemen emosi melalui ekspresi tulis dan gambar. Padahal, mengacu pada teori perkembangan emosional anak, Montessori (Crain, 2007) berpendapat bahwa anak usia sekolah dasar merupakan pemilik periode sensitif atau masa peka bagi anak, yaitu suatu periode yang mana suatu fungsi tertentu perlu dirangsang dan diarahkan sehingga tidak terhambat perkembangan anak di masa mendatang. Masa anak merupakan suatu fase yang sangat penting dan berharga, karena merupakan masa pembentukan dalam periode kehidupan manusia dewasa. Oleh karena itu, masa anak sering dipandang sebagai golden age (masa emas) bagi penyelenggara pendidikan. Masa anak juga merupakan fase yang sangat fundamental bagi perkembangan individu karena dalam fase tersebut terjadi peluang yang sangat besar untuk pembentukan dan perkembangan 
pribadi seseorang di masa-masa berikutnya.

Berdasarkan latar belakang di atas, peneliti berasumsi bahwa alangkah pentingnya jika penelitian dengan tema menulis dan menggambar diberikan sejak dini kepada subjek anak-anak, dengan pertimbangan bahwa perkembangan anak sangat penting untuk keberlanjutan di kehidupan mendatang. Dalam penelitian ini, peneliti memfokuskan pada tujuan untuk mengetahui efektivitas penurunan agresivitas siswa sekolah dasar melalui penggunaan Buku "Pelangi Hatiku". Hipotesis yang diajukan adalah ada perbedaan tingkat agresivitas sebelum dan sesudah diberikan $\mathrm{BPH}$; ada penurunan agresivitas pada siswa SD setelah diberikan $\mathrm{BPH}$.

\section{METODE PENELITIAN}

\section{Subjek Penelitian}

Subjek dalam penelitian ini berjumlah 19 siswa dengan beberapa karakteristik sebagai berikut: (1) anak laki-laki dan perempuan berusia antara 10-12 tahun, (2) tercatat sebagai siswa aktif di kedua SD Negeri di Yogyakarta,(3)sudah mampu membaca,menulis dan atau menggambar,(4)memiliki skor agresivitas sedang sampai dengan sangat tinggi berdasarkan hasil alat ukur yang telah diberikan pada saat prates.

\section{Desain Penelitian}

Desain penelitian ini adalah sebagai berikut :

$$
\text { KE: T1 X T2 T3 }
$$

\section{Keterangan:}

KE: KelompokEksperimen

T1: Pengukuran awal (prates)

T2: Pengukuran akhir (pascates)

T3: Pengukuran lanjutan (followup)

\section{Metode Pengumpulan Data}

Pengumpulan data dalam penelitian ini dilakukan dengan menggunakan skala agresivitas, Buku "Pelangi Hatiku", dan lembar follow-up. Berikut ini adalah metode pengumpulan data yang digunakan peneliti (lihat tabel 2).

Tabel 2. Metode Pengumpulan Data

\begin{tabular}{ll}
\hline Metode Pengumpulan Data & Alat Pengumpul Data \\
\hline Tertulis & Skala Agresivitas \\
Tulis dan gambar & Buku "Pelangi Hatiku" \\
Tulis & Lembar follow-up \\
\hline
\end{tabular}

Try-out skala agresivitas melibatkan 59 siswa-siswi sekolah dasar, yaitu 29 siswa kelas $V$ SD Negeri $Y$ dan 30 siswa kelas $V$ SD Negeri $X$. Hasil try-out ini dianalisis dan hasilnya menunjukkan bahwa 8 aitem dinyatakan gugur karena berada di bawah batas kritis 0.300 . Nilai reliabilitas statistik cronbach's alpha sebesar 0.903 pada putaran pertama dan 0.919 pada putaran kedua. 


\section{Intervensi dan Prosedur Penelitian}

1. Building rapport

Building rapport diberikan selama kurang lebih 20 menit setelah jam istirahat, pukul 9.20 sampai dengan pukul 9.40, sesuai izin dari wali kelas. Beberapa pendekatan yang peneliti lakukan adalah dengan memperkenalkan diri, menyampaikan maksud dan tujuan, menyampaikan sekilas gambaran umum pelaksanaan penelitian dan menunjukkan satu contoh $\mathrm{BPH}$ yang akan diberikan kepada subjek setelah masa prates dilakukan.

2. Pelaksanaan uji coba skala (try-out terpakai)

Try-out ini melibatkan 59 siswa- siswi sekolah dasar, yaitu 29 siswa kelas V SD Negeri Y dan 30 siswa kelas V SD Negeri $X$. Hasil try-out ini peneliti gunakan sebagai data prates (try-out terpakai).

\section{Pengukuran awal (prates)}

Setelah hasil try-out terpakai (prates) didapatkan, peneliti menggabungkan hasil tersebut untuk dilakukan penyeleksian subjek dengan cara mengelompokkan berdasarkan lima kategorisasi, yaitu sangat rendah, rendah, sedang, tinggi, dan sangat tinggi. Subjek dengan hasil kategorisasi sedang sampai dengan sangat tinggi masuk sebagai subjek penelitian.

Tabel 2. Deskripsi Kategori Subjek Penelitian Berdasarkan Hasil Prates

\begin{tabular}{|c|c|c|c|}
\hline \multirow{2}{*}{ Kategori } & \multirow{2}{*}{ Norma } & \multicolumn{2}{|c|}{ Kelompok Eksperimen } \\
\hline & & $\mathbf{n}$ & Persen \\
\hline Sangat Rendah & $x<43,422$ & 0 & $0 \%$ \\
\hline Rendah & $43,422<x<60,637$ & 0 & $0 \%$ \\
\hline Sedang & $60,637<x<77,842$ & 12 & $48 \%$ \\
\hline Tinggi & $77,842<x<95.052$ & 13 & $52 \%$ \\
\hline Sangat Tinggi & $x>95.052$ & 0 & $0 \%$ \\
\hline & Jumlah & 25 & $100 \%$ \\
\hline
\end{tabular}

4. Pemberian Buku "Pelangi Hatiku" (intervensipenelitian)

Pemberian Buku "Pelangi Hatiku" merupakan bentuk intervensi yang diberikan dalam pelaksanaan eksperimen ini. Intervensi ini diberikan mulai tanggal 16 Juli sampai dengan 3 Agustus 2012 (20 hari). Selama masa tersebut, peneliti melakukan empat sesi kunjungan, yaitu tanggal 18, 23, 26, dan 30 Juli 2012 untuk memastikan bahwa $\mathrm{BPH}$ benar-benar diisi oleh subjek dan melihat progress report selama masa eksperimen berlangsung.

Ada beberapa instruksi yang peneliti lakukan sebelum intervensi diberikan: 
a. Membagikan BPH kepada seluruh subjek eksperimen secara merata.

b. Membacakan peraturan dan tata cara pengisian BPH selama kurang lebih 10 menit, termasuk memastikan bahwa semua subjek mendengarkan penjelasan peneliti.

c. Memberikan kesempatan kepada seluruh subjek untuk bertanya jika ada penjelasan tata cara pengisian $\mathrm{BPH}$ yang belum dimengerti (5 menit).

d. Memberikan contoh cara penggunaan pensil warna pada tempurung "kura-kura" BPH (10 menit).

e. Peneliti mempersilakan kepada subjek untuk menghubungi nomor peneliti yang telah peneliti tuliskan pada papan tulis, jika ada hal penting yang perlu ditanyakan selama penelitian berlangsung.

f. Memberikan ketegasan kepada subjek untuk merahasiakan isi $\mathrm{BPH}$ masing-masing dari siapapun. BPH hanya rahasia antara subjek dengan peneliti dan dengan Tuhan (5 menit).

Selanjutnya untuk menjaga ancaman validitas internal, peneliti berusaha menekankan kepada subjek untuk benar-benar menjaga rahasia isi $\mathrm{BPH}$ masing-masing dari siapapun termasuk teman satu bangku atau satu kelas.

\section{Pengukuran akhir (pascates)}

Pascates dilakukan pada tanggal 3 dan 4 Agustus 2012 di sekolah masingmasing. Pascates berlangsung dari pukul 9.20 sampai dengan pukul 10.15 WIB termasuk building rapport.

Tabel 3. Perubahan Jumlah Subjek Setelah Dilakukan Pascates

\begin{tabular}{llcc}
\hline \multirow{2}{*}{ Kategori } & Norma & \multicolumn{2}{c}{ Kelompok Eksperimen } \\
\cline { 3 - 5 } & $\mathrm{x}<43,422$ & $\mathbf{n}$ & Persen \\
\hline Sangat Rendah & $43,422<\mathrm{x}<60,637$ & 3 & $0 \%$ \\
Rendah & $60,637<\mathrm{x}<77,842$ & 12 & $63 \%$ \\
Sedang & $77,842<\mathrm{x}<95.052$ & 4 & $21 \%$ \\
Tinggi & $\mathrm{x}>95.052$ & 0 & $0 \%$ \\
Sangat Tinggi & & $\mathbf{1 9}$ & $\mathbf{1 0 0} \%$ \\
\hline \multicolumn{1}{c}{ Jumlah } & & &
\end{tabular}

Peneliti menggunakan individu subjek pada penelitian ini. Didapatkan, dengan kategori agresivitas sedang pada saat prates, terdapat 25 subjek pada sampai dengan sangat tinggi sebagai kelompok eksperimen. Jumlah subjek 
tersebut mengalami perubahan setelah pascates dan masa pemberian Buku Pelangi Hatiku (BPH) dianggap selesai, yaitu sejumlah 6 subjek tidak mengumpulkan $\mathrm{BPH}$, sehingga peneliti tidak dapat menganalisis hasil tulisan 6 subjek apakah benar-benar menulis atau tidak. Dengan demikian, pada kelompok eksperimen masih tersisa 19 subjek pada saat pascates.

\section{Pengukuran lanjutan (follow-up)}

Follow-up pada penelitian ini dilakukan pada tanggal 6 Agustus 2012, tiga hari setelah pemberian pascates. Subjek berjumlah sama dengan pascates, yaitu 19 subjek. Dilakukan di ruang kelas VI-B SD Negeri X pada pukul 9.40 sampai dengan 10.45 atas izin wali kelas. Pengukuran lanjutan dilakukan dengan meminta subjek untuk mengisi lembaran follow-up.

\section{Metode Analisis Data}

Analisis data untuk melihat perbedaan agresivitas dalam penelitian ini menggunakan non-parametrik onesample Kolmogorov-Smirnov program SPSS for windows version 16. Sementara untuk melihat penurunan agresivitas setelah pemberian BPH menggunakan analisis data Mann-Whitney Test program SPSS for windows version 16. Selain itu, dilakukan juga analisis kualitatif dengan menganalisis hasil tulisan-tulisan subjek pada $\mathrm{BPH}$, hasil laporan subjek pada saat kunjungan, dan hasil follow-up yang telah diberikan.

\section{HASIL PENELITIAN}

\section{Deskripsi Statistik}

Secara keseluruhan data deskriptif statistik prates dan pascates kelompok eksperimen dapat dilihat pada tabel 5 .

Tabel 5. Deskripsi Prates dan Pascates Agresivitas

\begin{tabular}{lcc}
\hline \multirow{2}{*}{ Klasifikasi } & \multicolumn{2}{c}{ Kelompok Eksperimen } \\
\cline { 2 - 3 } & Prates & Pascates \\
\hline Skor Minimum & 61 & 54 \\
Skor Maksimum & 93 & 89 \\
Rerata & 21,37 & 17,63 \\
Std. Deviasi & 10.18 & 9.06 \\
Jumlah Subjek (N) & 25 & 19 \\
\hline
\end{tabular}

\section{Hasil Uji Hipotesis}

Uji hipotesis untuk mengetahui perbedaan tingkat agresivitas sebelum dan sesudah $\mathrm{BPH}$ ditunjukkan dari nilai $\mathrm{p}$ yang signifikan pada analisis data nonparametrik one-sample KolmogorovSmirnov ( $p=0,407$ atau $p>0,05$ ) dengan distribusi data normal pada kelompok yang sama sebelum dan sesudah diberikan $\mathrm{BPH}$.

Penurunan agresivitas setelah pemberian $\mathrm{BPH}$ ditunjukkan melalui nilai $p$ yang signifikan pada analisis data Mann-Whitney Test $(p=0,299$ dengan $p$ $>0,05)$. Nilai rerata agresivitas mengalami penurunan antara sebelum dan sesudah diberikan BPH (Mean sebelum $=21,37$; mean sesudah $=$ $17,63)$ dan penurunan kecenderungan agresivitas setelah diberikan $\mathrm{BPH}$ sebanyak $9.59 \%$. 


\section{PEMBAHASAN}

Penelitian ini bertujuan untuk mengetahui efektivitas penggunaan Buku "Pelangi Hatiku" (BPH) terhadap penurunan agresivitas siswa sekolah. Berdasarkan uji hipotesis yang telah dilakukan, nilai rerata agresivitas mengalami penurunan antara sebelum dan sesudah diberikan BPH (Mean sebelum = 21,37; mean sesudah = 17,63) dengan sumbangan efektivitas penurunan kecenderungan agresivitas setelah diberikan BPH sebanyak 9.59\%. Dengan demikian, hipotesis penelitian ini yang berbunyi ada perbedaan tingkat agresivitas sebelum dan sesudah diberikan BPH; ada penurunan agresivitas pada siswa SD setelah diberikan $\mathrm{BPH}$, diterima.

Perbedaan tingkat agresivitas sebelum dan sesudah BPH ditunjukkan dari nilai $p$ yang signifikan pada analisis data non-parametrik one-sample Kolmogorov-Smirnov ( $p=0,407$ atau $p$ $>0,05)$ dengan distribusi data normal pada kelompok yang sama sebelum dan sesudah diberikan BPH. Penurunan agresivitas setelah pemberian $\mathrm{BPH}$ ditunjukkan melalui nilai $p$ yang signifikan pada analisis data MannWhitney Test $(p=0,299$ dengan $p>$ $0,05)$. Nilai rerata agresivitas juga mengalami penurunan antara sebelum dan sesudah diberikan BPH (Mean sebelum = 21,37; mean sesudah = 17,63), sehingga berdasarkan angka- angka statitstik tersebut dapat diketahui efektivitas penurunan kecenderungan agresivitas setelah diberikan BPH adalah sebanyak $9.59 \%$.

Setiap individu, tidak terkecuali siswa sekolah dasar, tentu memiliki pikiran, pengalaman, dan emosi. Bahagia, sedih, kecewa, marah, dan takut merupakan deretan contoh emosi yang dimiliki setiap individu. Dari beberapa contoh tersebut, marah adalah salah satu bentuk agresivitas (Buss \& Perry, 1992). Selain marah, contoh emosi, pikiran, dan pengalaman atau perilaku yang masuk kategori agresif di antaranya adalah mencemooh, memusuhi, menghina, memukul, dan yang lebih ekstrim membunuh.

Campbell (Utami \& Kumara, 2007) menjelaskan bahwa terdapat berbagai macam cara untuk mengekspresikan emosi, antara lain dengan creative writing. Dalam metode creative writing, anak dapat membuat peta pikiran dimulai dari perasaan anak sebagai konsep sentral. Asosiasi anak dapat disintesiskan ke dalam puisi atau paragraf. Catatan atau cerita harian tentang kesadaran emosi dari anak juga menjanjikan sebuah penyaluran emosi yang positif. Lebih lanjut, Campbell (Utami \& Kumara, 2007) menyatakan bahwa anak-anak dapat mengeksplorasi identitas diri melalui tulisan yang memungkinkan adanya kesadaran diri, penerimaan diri, aktualisasi diri, dan pembukaan diri. Gross dan Hayne (Utami \& Kumara, 
2007) menambahkan bahwa anak-anak dapat menceritakan dan menuangkan pengalaman emosional yang dirasakan dengan cara memberikan kesempatan kepada anak untuk menggambar.

Sementara itu keterkaitan antara emosi dan agresivitas telah dibahas dalam Ensiklopedia Psikologi Sosial oleh Manstead dan Hewstone (Faturochman, 2009). Agresivitas meskipun berada pada level behavior (perilaku), namun tidak bisa dilepaskan dari emosi yang merupakan level afeksi individu karena emosi merupakan aspek dari segala macam bentuk perilaku. Tidak jarang dijumpai bahwa perilaku seseorang dipengaruhi oleh emosi serta kognisinya. Penelitian Baron dan Byrne (2005) menemukan bahwa agresivitas dipengaruh oleh kompleksitas perpaduan antara emosi dan kognisi individu. Seringkali kognisi memengaruhi reaksi emosi seseorang dan sebaliknya emosi seringkali mengasah kognisi seseorang. Secara bersama-sama, kompleksitas pola pikir dan emosi yang dialami individu akan memengaruhi perilaku agresi seseorang terhadap orang lain.

Selanjutnya, untuk melihat adanya perbedaan agresivitas anak dalam penelitian ini, dibutuhkan media yang tidak sekedar hanya mengetahui ada atau tidaknya perbedaan, tetapi juga bermanfaat bagi anak dalam mengenalkan, mengungkapkan, dan mengontrol emosi yang dirasakan. Media yang peneliti maksud dalam penelitian ini adalah Buku Pelangi Hatiku (BPH). Sejumlah karakteristik yang dimiliki BPH seperti lembaran bergaris, lembaran polos, kertas warna-warni, dan juga gambar "kura-kura" dapat dimanfaatkan anak untuk mengekspresikan, mengenal, dan mengontrol semua jenis perasaan, pikiran, pengalaman, dan emosi yang dirasakan anak secara bebas, baik tulis maupun gambar. Dengan menulis, anak akan terbiasa bersahabat dan berkomunikasi dengan alam serta mempertajam intuisi diri. Dengan menulis, anak bebas mengekspresikan diri, mengenali, dan memahami emosi baik dari diri sendiri maupun orang lain. Anak juga akan belajar berempati dan menempatkan diri. Sikap seperti ini merupakan salah satu modal untuk berperilaku secara tepat dalam lingkup sosial (Iriani, 1998).

Jika tidak mampu mengungkapkan dalam bentuk tulisan, anak bisa mengungkapkan dalam bentuk gambar. Dengan menggambar, individu terlatih untuk mengekspresikan diri (Iriani, 1998). Ekspresi kemarahan atau agresi dapat tertuang tanpa konsekuensi merusak lingkungan fisik atau merugikan orang lain. Ekspresi ini dapat semakin komunikatif bila seseorang semakin sering menggambar (ada frekuensi), di samping menggambar juga merupakan pengenalan dan penuangan ide maupun emosi secara konkret yang biasanya bersifat abstrak. Menggambar 
memungkinkan seseorang memahami bahwa ada ide-ide, perasaan, dan pelukisan emosi yang bisa dituangkan dalam seni gambar. Melalui cara ini anak belajar membaca emosi diri mereka sendiri dan menangkap ide-ide serta imajinasi (Iriani, 1998). Menggambar, sebagaimana dijelaskan Anoviyanti (2008), mampu mengungkap pengalaman inner experiences (pengalaman batin) tanpa harus dijelaskan dengan kata-kata atau tulisan.

Lembaran-lembaran BPH yang berwarna-warni, memberikan kenyamanan dan kesenangan bagi anak selama mengisi BPH. Lembaranlembaran tersebut juga berguna sebagai alat pengingat ataupun dokumentasi pribadi bagi anak dari peristiwaperitstiwa yang telah dialami dan ditulis oleh anak (Sulistyowati, 2011). Peristiwaperistiwa tersebut yang kemudian akan menjadi pelajaran berharga sekaligus sebagai refleksi dan introspeksi pribadi di masa yang akan datang (Utami \& Kumara, 2007).

Berikut adalah tiga temuan yang mengungkap bahwa proses menulis dapat menurunkan agresivitas anak dari hasil follow-up yang dilakukan pada subjek penulis di Buku "Pelangi Hatiku":

"Biasanya sebelum punya buku 'Pelangi Hatiku' aku curhat dengan teman. Setelah punya, menulis di buku 'Pelangi Hatiku'. Perasaanku biasa saja sebelum nulis. Setelah nulis lega karena aku bisa menumpahkan kesedihanku dan kesenanganku dan kemarahanku." (subjek 1, TR)

"Jika aku marah atau sedih biasanya aku mendengarkan lagu atau menyendiri dari siapapun. Setelah aku punya buku 'Pelangi Hatiku' semua kemarahanku, kesedihanku dan kebahagiaanku aku curahkan di dalam buku 'Pelangi Hatiku'. Setelah menulis aku langsung lega dan terasa udah lega semuanya." (subjek 4, NRT)

"Sebelum punya, biasanya kalau marah atau sedih, berdiam diri. Setelah punya aku menulis di buku 'Pelangi Hatiku'. Perasaan yang di dalam hati dan di dalam otak merasa berkurang." (subjek 15, BRT)

Kelemahan dalam desain $\mathrm{BPH}$ sebagai intervensi dalam penelitian ini adalah hanya melalui expert judgment dari pembuat pertama $\mathrm{BPH}$ dan satu orang ibu rumah tangga, meskipun telah ditemukan bahwa 4 subjek pada penelitian ini merasakan manfaat $\mathrm{BPH}$ (subjek 1, 4, 7, 15). Sebaiknya sebelum intervensi BPH diberikan kepada subjek penelitian, dilakukan terlebih dahulu uji coba kepada subjek pre-eliminary.

Selanjutnya, peneliti akan menjelaskan bahwa berbagai macam emosi yang dimiliki anak usia sekolah dasar tidak dapat dipisahkan dengan perkembangan sosio-emosional anak itu sendiri yang semakin berbeda dan kompleks (Izzaty, Suardiman, Ayriza, Purwandari, Hiryanto, \& Kusmaryani, 2008). Interaksi anak dengan keluarga dan anak dengan teman sebayanya 
memiliki peranan yang sangat penting. Sekolah dan guru juga ikut menjadi hal berpengaruh dalam hidup anak setelah anak berada di luar sekolah. Belum lagi pemahaman tentang diri dan pergaulan yang semakin luas dengan sesama teman sekolah atau teman sebaya lainnya. Beberapa hal di atas sangat berpotensi untuk menjadikan emosi dan perilaku anak sering berubah setiap saat. Ronen (Mukhtar \& Hadjam, 2006) berpendapat bahwa proses penilaian diri sendiri oleh anak-anak yang mengalami perilaku acting-out (seperti perilaku agresif dan suka melawan) dipengaruhi oleh berbagai hal seperti perspektif anak tentang dirinya dan situasi pada saat penilaian (misalnya, mood anak, rasa lapar, kelelahan, serta kehadiran orang tua dan guru).

Secara umum, penelitian ini mendukung pernyataan Izzaty dkk (2008) bahwa emosi anak berlangsung relatif lebih singkat (sebentar), hanya beberapa menit, bersifat tiba-tiba, dan mudah berubah. Tidak seperti emosi orang dewasa yang berlangsung lebih lama. Adanya emosi anak yang menghasilkan perilaku agresif bersifat pendek menjadikan anak mulai belajar bahwa ungkapan emosi yang kurang baik tidak dapat diterima oleh lingkungan. Anak selama masa interaksi semakin belajar untuk mengendalikan ungkapanungkapan emosi yang kurang diterima, seperti marah, mencemooh, dan sebagainya. Perubahan dan sering bergantinya emosi anak tersebut memungkinkan berubah pula perilaku agresif subjek serta minat subjek dalam mengisi BPH selama masa penelitian ini berlangsung.

\section{SIMPULAN DAN SARAN}

\section{Simpulan}

Berdasarkan hasil analisis data dan pembahasan yang telah dijelaskan, dapat disimpulkan bahwa secara kuantitatif terbukti ada perbedaan tingkat agresivitas sebelum dan sesudah diberikan BPH. Ada penurunan nilai rerata agresivitas antara sebelum dan sesudah diberikan $\mathrm{BPH}$ (Mean sebelum $=21,37$; mean sesudah $=17,63)$ dengan sumbangan efektivitas sebanyak $9.59 \%$. Secara kualitatif adanya $\mathrm{BPH}$ menjadi alternatif media bagi para siswa untuk mengungkapkan ide, emosi, dan pengalaman yang dirasakan.

\section{Saran}

1. Bagi Subjek Penelitian

Diharapkan subjek tetap konsisten menggunakan Buku "Pelangi Hatiku" (BPH) sebagai media untuk menuangkan pengalaman, ide, dan emosi secara tepat sehingga perilaku agresif bisa terminimalisir.

2. Bagi Guru, Sekolah dan Pemerintah Menggunakan BPH dan hasil penelitian ini sebagai rujukan model intervensi dalam menangani sejak 
dini siswa-siswi yang memiliki masalah agresivitas. Sebagai saran, jika BPH diberikan dalam jangka waktu yang lebih lama, misalnya satu semester atau lebih, maka akan bisa lebih besar sumbangan efektivitas yang diberikan. BPH ini juga dapat sebagai media intervensi baik dalam konseling dan training di sekolahsekolah sebagai pelengkap intervensi yang sudah ada sebelumnya.

3. Bagi Peneliti Selanjutnya

a. Selalu mengontrol validitas internal dan eksternal yang dapat memengaruhi hasil penelitian eksperimen, seperti difusi dan imitasi selama eksperimen berlangsung.

b. Memperjelas prosedur intervensi BPH dan melakukan uji coba BPH terlebih dahulu kepada beberapa subjek preeliminary sebelum benar-benar diberikan kepada subjek penelitian. Tidak cukup hanya melakukan validitas isi atau expert judgment.

\section{DAFTAR PUSTAKA}

Akbar, Z. \& Afiatin, T. (2009). Pelatihan Manajemen Emosi Sebagai Program Pemulihan Depresi pada Remaja Korban Gempa Bumi. Jurnal Intevensi Psikologi, 1, 107124.

Anantasari, M.L. (2006). Menyikapi Perilaku Agresif Anak. Yogyakarta: Kanisius.
Anoviyanti, S.R. (2008). Terapi Seni Melalui Melukis pada Pasien Skizofrenia dan Katergantungan Narkoba. ITB Journal of Visual Art and Design, 3, 72-84.

Baron, R.A. \& Byrne, D. (2005). Social Psychology Tenth Edition. Alih bahasa: Ratna Djuwita. Jakarta: Erlangga.

Berkowitz, L. (2003). Emosional Behavior: Mengenali Perilaku dan Tindakan Kekerasan di Lingkungan Sekitar Kita dan Cara Penanggulangannya. Penerjemah: Hartanti Woro Susianti. Jakarta: CV. Teruna Grafica.

Buss, A.H. \& Perry, M. (1992). The Agression Questionaire. Journal of Personality and Psychology, 63, 452-459.

Crain, W. (2007). Theories of Development, Concepts and Applications Third Edition. Alih bahasa: Yudi Santoso. Yogyakarta: Pustaka Pelajar.

Faturochman. (2009). Pengantar Psikologi Sosial. Yogyakarta: Penerbit Pinus.

Iriani, N. (1998). Seni: Wahana Untuk Menajamkan Rasa dan Memintarkan Emosi. Jurnal Psikologika, 5 (3), 19-25.

Izzaty, R.E., Suardiman, S.P., Ayriza, Y., 
Purwandari, Hiryanto, \& Kusmaryani, R.E. (2008). Perkembangan Peserta Didik. Yogyakarta: UNY Press.

Kokko, K., L., Pulkkinen, K.K., Huesmann, L. R., Dubow, E. F. \& Boxer, P. (2009). Intensity of Aggression in Childhood as Predictor of Different Forms of Adults Aggression: A Two-Country (Finland and the United States) Analysis. Journal of Research on Adolescence, 19 (1), 9-34.

Kompas. (23 Desember, 2011). Tawuran: Tradisi Tak Berkesudahan. Diakses pada tanggal 23 Desember 2012 pukul 12.15 WIB dari http://edukasi.kompas.com/read/2 011/12/23/10210953/Tawuran.Tr adisi.Buruk.Tak.Berkesudahan.

Kompas. (7 Februari, 2012). Memukul Picu Gangguan Emosi Anak. Diakses pada tanggal 30 April 2012 pukul 15.44 WIB dari http://health.kompas.com/read/20 12/02/07/10375025/Memukul.Pic u. Gangguan.Emosi.Anak.

Lestari, I. (2010). Hubungan Kebiasaan Menulis Buku Harian dengan Keterampilan Intrapersonal pada Remaja Akhir. Skripsi (tidak diterbitkan). Surabaya: Fakultas Psikologi Universitas Surabaya.

Mukhtar, D.Y. \& Hadjam, N.R. (2006).
Efektivitas Art Therapy Untuk Meningkatkan Keterampilan Sosial Pada Anak Yang Mengalami Gangguan Perilaku. Jurnal Psikologia, 2, 16-24.

Mundia, L. (2006). Aggressive Behavior among Swazi Upper Primary and Junior Secondary Students: Implications for Ongoing Educational Reforms Concerning Inclusive Education. International Journal of Special Education, 21, 58-67.

Pennebaker, J.W. (1997a). Writing About Emotional Experiences as a Therapeutic Process. Psychological Science-American Psychology Society, 8, 162-166.

Pennebaker, J.W. (1997b). Opening Up: The Healing Power of Expressing Emotions. New York: Guilford Press Publications.

Republika. (15 Juli, 2007). TBKita Gairah Membaca Anak-anak Desa. Diakses pada tanggal 28 September 2012 pukul 9.57 WIB dari http://www.republika.co.id/korandetail.asp?id $=300162 \&$ kat_id $=3$ 19.

Sari, H. \& Kurniawan, I.N. (2004). Pengaruh Pelatihan Kecerdasan Emosi Terhadap Penurunan Agresivitas Anak di Sekolah. Jurnal 
Psikologika, 9 (18), 34-44.

Siswanto \& Prawitasari, J.E. (2003). Pengaruh Menulis Pengalaman Emosional Terhadap Simtomsimtom Depresi Pada Mahasiswa. Jurnal Sosio-humanika, 16A (1), 25-42.

Sulistyowati, T. (2011). Buku Harianku, Sabahat Sejatiku. Yogyakarta: Citra Aji Parama.

Syaodih, E. (2003). Perkembangan Anak Usia Dini: Bahan Pelatihan Pembelajaran Terpadu Yayasan Pendidikan Salman Al Farisi. Diakses pada tanggal 13 Maret 2012 pukul 13.20 WIB dari http://file.upi.edu.

Tempo. (8 Februari, 2012). Sering Ditampar Membuat Anak Jadi Lebih Agresif. Diakses pada tanggal 2 Maret 2012 pukul 12.29 WIB dari http://www.tempo.co/read/news/2012/02/08/174382582/Seri ng-Ditampar-Membuat-Anak-JadiLebih-Agresif.

Tremblay, R.E. (2008). Development of Physical Aggression from Early Childhood to Adulthood. Encyclopedia on Early Childhood Development. Montreal: Centre of Excellence for Early Childhood Development.

Utami, D.S. (2004). Manajemen Emosi Melalui Buku "Pelangi Hatiku":
Studi Kasus Pada Pasien AnakAnak Rawat (Hospitalized Children). Skripsi (tidak diterbitkan). Yogyakarta: Fakultas Psikologi Universitas Gajah Mada.

Utami, D.S. \& Kumara, A. (2007). Manajemen Emosi pada Pasien Anak Rawat Inap (Hospitalized Children) Melalui Ekspresi Tulis dan Gambar. Jurnal Psikologika, 12, (23), 5-20.

Wardhani, Y. F. (2007). Penerapan Terapi Menulis Untuk Menurunkan Agresi pada Remaja dengan Lambat Belajar (Studi Kasus pada Seorang Remaja Putri yang Tinggal di Panti Asuhan). Buletin Penelitian Sistem Kesehatan, 10, 158-166.

Wilson, S. J. \& Mark, W. L. (2003). The Effects of School-Based Intervention Programs on Aggressive Behavior: A MetaAnalysis. Journal of Consulting and Clinical Psychology, 71, 136-149.

Winarsih, A. (2007). Upaya Mengatasi Agresifitas Negatif Siswa Melalui Layanan Bimbingan Individu Bagi Siswa Kelas X. Jurnal Widyatama, 4, 63-68. 